\title{
Market Integration, Return and Volatility Dynamics: Empirical Evidence from African Stock Markets
}

\author{
Kashif Saleem ${ }^{1}$, Mikael Collan ${ }^{1}$, Sheraz Ahmed ${ }^{1} \&$ Antwi Kofi Gyasi ${ }^{1}$ \\ ${ }^{1}$ Lappeenranta University of Technology, School of Business, Lappeenranta, Finland \\ Correspondence: Kashif Saleem, Lappeenranta University of Technology, School of Business, Lappeenranta, \\ Finland. E-mail: kashif.saleem@lut.fi
}

Received: June 17, 2014

Accepted: July 21, 2014

Online Published: August 25, 2014

doi:10.5539/ibr.v7n9p30

URL: http://dx.doi.org/10.5539/ibr.v7n9p30

\begin{abstract}
This study examines the extent of integration of liberalized African equity markets with the US, the world, the BRIC countries, and other emerging markets. Specifically, we examine the relationship between seven African markets, namely those of Kenya, South Africa, Mauritius, Tunisia, Egypt, Zambia, and Morocco with the World market index and the US market index. In addition, the relationship between the African markets and the BRIC countries, and the Emerging Market Index is analyzed. We investigate, whether there are pure contagion effects in the markets under consideration during the (US) financial crisis of 2008. A bivariate VAR-GARCH-BEKK model is used in the analysis. Our empirical findings support the notion that these markets are still green for investment and provide portfolio benefits. Diversification benefits with African stock markets are dwindling over the years, but these benefits do not disappear entirely. Furthermore, the increased correlations between the African and the developed markets are still small, in comparison with correlations found between developed markets
\end{abstract}

Keywords: GARCH-BEKK, volatility spillovers, contagion, African equity markets, portfolio diversification

\section{Introduction}

Many frontier and emerging economies have implemented policies with the objective of liberalizing their equity markets, this is true also for many African markets - the focus area of this paper. The objective of this study is to establish whether, and to what extent, the liberalized African stock-markets are integrated with the US markets and the World Markets Index (WMI).

African equity market liberalization has opened the African equity markets to foreign investors, and paved the way for African investors to invest in foreign equities. (Note 1) Among other things, equity market liberalization may result in diversification benefits (see, e.g., Divecha et al., 1992; Harvey, 1993; and Wilcox, 1992) and lead to a lower cost of equity capital as a result of a lowering rate of return required by an increased number of investors. Foreign and local investors also share any potential risks, and the presence of an increased number of investors can be expected to make liberalized equity markets more liquid. Equity market liberalization results in financial integration, which explains the co-movement of any two markets (see, e.g., Bekaert \& Urias, 1996; Tai, 2007; Billio \& Caporin, 2010; Bekaert \& Harvey, 1995; Bekaert et al., 2002, 2003, 2005 \& 2006 among others). Furthermore, in periods of crisis, increased volatility and co-movements between markets may result in, what is commonly called contagion effects (see, e.g., Forbes \& Rigobon, 2002; Dungey et al., 2004; Saleem, 2009; Gebka \& Serwa, 2007; Miyakoshi, 2003; Zhou et al., 2012; Beirne et al., 2010; Singh et al., 2010 among others).

Liberalization of the African stock markets and integration of these markets into the world markets can be said to be of high level of importance to the field of finance, from the point of view of considering the growth potential of the African markets, and the potential benefits they present for portfolio diversification. Due to this importance, it is interesting to investigate the liberalization process of African stock markets, the performance of these markets over the years, the stability, the impact on economic growth, and the role of these markets on the global financial scene. Surprisingly, previous literature on the liberalization of the African markets is rather scarce; some existing previous works include Fowowe (2011, 2013), Ahmed and Suardi (2009), Kuttu (2014), Karikari (2010), Misati and Nyamongo (2011), and Saleem (2013).

The major move toward financial liberalization in Africa generally started in the late 1980s, with South African 
markets as the pioneer. Over the years, researchers have studied the impact of financial liberalization on Africa's economic development with mixed results; some showing positive effects on the development from the liberalization, others showing negative effects, and still others showing undecided results. Here we study the extent, to which the liberalized African markets are integrated to the World markets and to the US markets. Specifically, we examine the relationship between seven African markets, namely those of Kenya, South Africa, Mauritius, Tunisia, Egypt, Zambia, and Morocco with the WMI and the US Market Index (USMI). In addition, the relationships between the African markets and the BRIC countries and between the African Markets and the Emerging Market Index (EMI) are analysed. Finally, this study investigates, whether there are pure contagion effects in the markets under consideration during the (US) financial crisis of 2008.

We use a bivariate VAR-GARCH- BEKK model in the analysis. Before the analysis some data pre-processing was performed through econometric data purification to remove the effect of thin trading following the footsteps of Miller et al. (1994), Appiah-Kusi et al. (2003), and Mlambo et al. (2005). Thin trading, also known as non-trading, or inconsistency of trading, is a relevant and a well-known feature in African markets, and if not removed from data, may trigger inconsistencies and bias in the obtained results. Our results confirm previous results and show that South African and Egyptian stock markets are highly integrated with the US and the World markets. In addition, we find that Kenyan markets are also well-integrated with the US and the World markets, in terms of bi-directional volatility and shock transmissions with the US and the World markets.

The paper proceeds as follows: in the next section the used bivariate GARCH model is shortly presented and specified, then the data used and descriptive statistics are presented. This is followed by a presentation of obtained results, and finally, the paper concludes with a short summary and a discussion.

\section{Model Specification}

The Autogressive Conditional Heteroscedasticity (ARCH) process proposed by Engle (1982) and the generalised ARCH (GARCH) by Bollerslev (1986), are both well-known methods in volatility modelling of stock returns. In examining market integration between countries, however, a multivariate GARCH approach is commonly preferred over univariate settings. We start our empirical specification with a bivariate VAR-GARCH $(1,1)$ model that accommodates each market's returns, and the returns from the other (compared to) markets lag one period (Note 2).

$$
\begin{gathered}
{\left[\begin{array}{l}
r_{1, t} \\
r_{2, t}
\end{array}\right]=\left[\begin{array}{l}
a_{1,0} \\
a_{2,0}
\end{array}\right]+\left[\begin{array}{ll}
\beta_{1,1} & \beta_{1,2} \\
\beta_{2,1} & \beta_{2,2}
\end{array}\right]\left[\begin{array}{l}
r_{1, t-1} \\
r_{2, t-1}
\end{array}\right]+\left[\begin{array}{l}
\mu_{1, t} \\
\mu_{2, t}
\end{array}\right]} \\
u_{t} \mid \Omega_{t-1} \sim N\left(0, H_{t}\right)
\end{gathered}
$$

where $\boldsymbol{r}_{\boldsymbol{t}}$ is an $\mathbf{n} \times \mathbf{1}$ vector of daily returns, at the time $\mathbf{t}$ for each market. The $\mathbf{n} \times \mathbf{1}$ vector of random errors $\boldsymbol{\mu}_{t}$ represents the innovation for each market at time $\mathbf{t}$, with its corresponding $\mathbf{n} \times \mathbf{n}$ conditional variance-covariance matrix $\boldsymbol{H}_{t}$. The market information available at time t-1 is represented by the information set $\boldsymbol{\Omega}_{t-1}$. The $\mathbf{n} \times \mathbf{1}$ vector, $\boldsymbol{\alpha}$, represents the constant. The "own market" mean spill-overs and the cross-market mean spill-overs are measured by the estimates of matrix $\boldsymbol{\beta}$ elements, the parameters of the vector autoregressive term. This multivariate structure thus facilitates the measurement of the effects of innovations in the mean stock returns of one series on its own lagged returns, and those of the lagged returns of other markets. Given the above expression, and following Engle and Kroner (1995), the conditional covariance matrix can be stated as:

$$
H_{t}=C_{0}^{\prime} C_{0}+\gamma_{11}^{\prime} \varepsilon_{t-1} \varepsilon_{t-1}^{\prime} \gamma_{11}+\lambda_{11}^{\prime} H_{t-1} \lambda_{11}
$$

where the parameter matrices for the variance equation are defined as $\boldsymbol{C}_{\boldsymbol{0}}$, which is restricted to be lower triangular and two unrestricted matrices $\gamma_{11}$ and $\lambda_{11}$. Thus, the second moment can be represented by:

$$
H_{t}=C_{0}^{\prime} C_{0}+\left[\begin{array}{ll}
\gamma_{11} & \gamma_{12} \\
\gamma_{21} & \gamma_{22}
\end{array}\right]^{\prime}\left[\begin{array}{cc}
\varepsilon_{1, t-1}^{2} & \varepsilon_{1, t-1}, \varepsilon_{2, t-1} \\
\varepsilon_{1, t-1}, \varepsilon_{2, t-1} & \varepsilon_{2, t-1}^{2}
\end{array}\right]\left[\begin{array}{ll}
\gamma_{11} & \gamma_{12} \\
\gamma_{21} & \gamma_{22}
\end{array}\right]+\left[\begin{array}{ll}
\lambda_{11} & \lambda_{12} \\
\lambda_{21} & \lambda_{22}
\end{array}\right]^{\prime} H_{t-1}\left[\begin{array}{ll}
\lambda_{11} & \lambda_{12} \\
\lambda_{21} & \lambda_{22}
\end{array}\right]
$$

Following Engle and Kroner (1995), the above system can be estimated by the maximum likelihood estimation, which can be optimised by using the Berndt, Hall, Hall, and Hausman (BHHH, 1974) algorithm. From equations (4), we obtain the conditional log likelihood function $\mathrm{L}(\theta)$ for a sample of $\mathrm{T}$ observations:

$$
L(\theta)=\sum_{t=1}^{T} l_{t}(\theta)
$$




$$
l_{t}(\theta)=-\log 2 \pi-1 / 2 \log \left|H_{t}(\theta)\right|-1 / 2 \varepsilon_{t}^{\prime}(\theta) H_{t}^{-1}(\theta) \varepsilon_{t}(\theta)
$$

where $\theta$ denotes the vector of all the unknown parameters. Numerical maximisation of equation (4) yields the maximum likelihood estimates with asymptotic standard errors.

Finally, to test the null hypothesis that the model is correctly specified, or equivalently, that the noise terms, $\mu$, are random, the Ljung-Box Q-statistic is used. It is assumed to be asymptotically distributed as $\chi^{2}$ with ( $\mathrm{p}-\mathrm{k}$ ) degrees of freedom, where $\mathrm{k}$ is the number of explanatory variables.

\section{Data and Descriptive Statistics}

The data used in this study stretches over a period of fifteen (15) years starting from 19th of February 1998 to the 18th of February, 2013 generating 3913 daily observations. Daily price data is used here for the for the various indices, namely: MSCI Benchmark Index for the US (USMI), MSCI World Index (WMI), MSCI BRIC Countries Index, and MSCI Emerging Market Index (EMI). Kenyan, South African, Mauritian, Tunisian, Egyptian, Zambian, and Moroccan stock indices were gathered from DataStream. The price data was transformed to arithmetic percentage returns with the formula: $\boldsymbol{R e t}=((\boldsymbol{P t}-\boldsymbol{P t}-1) / \boldsymbol{P t}-1) * \mathbf{1 0 0}$. In the spirit of Miller et al (1994); Appiah-Kusi et al (2003); Mlambo et al (2005), this study adjusts for thin trading through a Moving Average (MA) process that fixes the problem of non-trading. An AR (1) of the form $\boldsymbol{r}=\boldsymbol{\alpha}+\boldsymbol{\beta} \boldsymbol{r} \boldsymbol{t}-\boldsymbol{1}+\boldsymbol{\varepsilon} \boldsymbol{t}$ and by using the residuals from the equation, the adjusted returns are calculated as follows: $r t a d j=\varepsilon t /(1-\beta)$.

BRIC

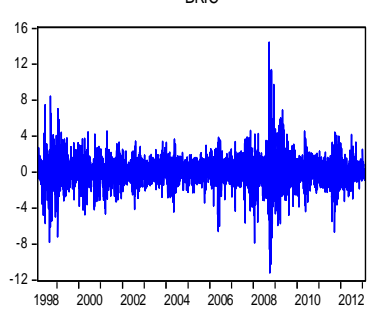

MAURITIUS

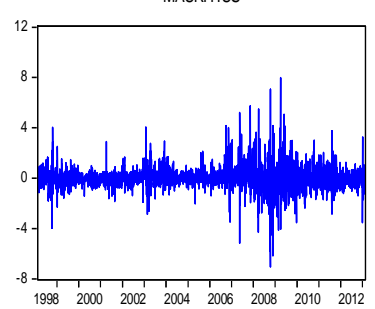

US

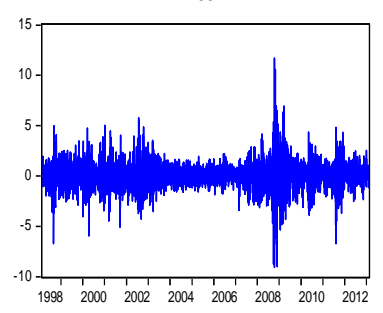

EGYPT

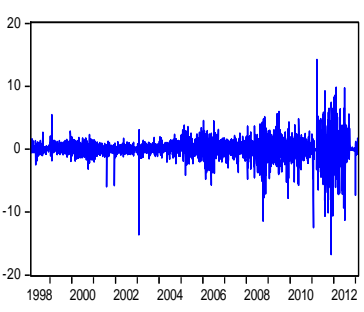

MOROCCO

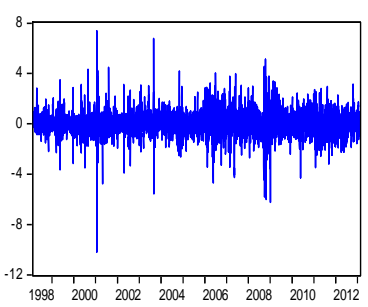

WORLD

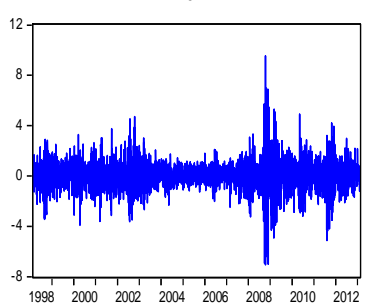

EM

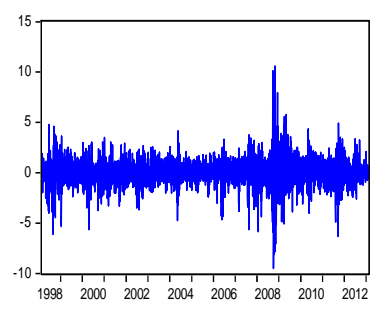

SA

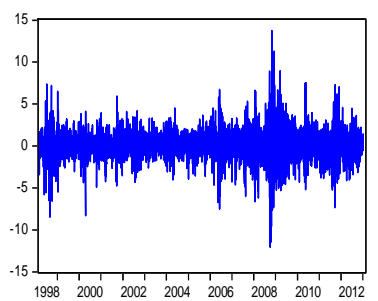

ZAMBIA

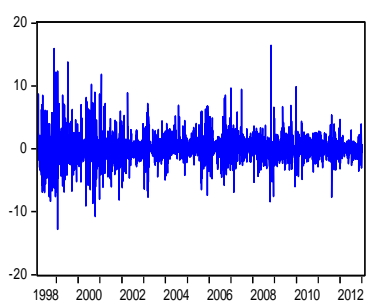

KENYA

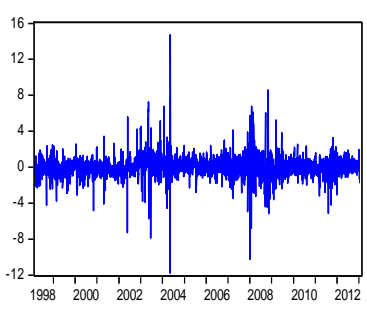

TUNISIA

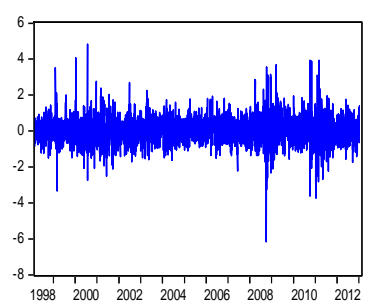

Figure 1. Arithmetic returns of all considered markets for the period, Feb 1998-Feb 2013

Table 1 presents the descriptive statistics of the data used. The first row of Table 1 shows the average annualized arithmetic mean of each return series used. During the time period of the study, the US markets earned $29.6 \%$ on average, whereas the average annual return of WMI, EMI, and the BRIC markets were $23.3 \%, 53.7 \%$, and $61.0 \%$, respectively. Of the seven African stock markets, Zambia has the highest return of $102 \%$ per annum, followed by the South African markets who on average have annual return of $84 \%$. The lowest earning market of the seven was the Kenyan market, with an annual return of approximately $13 \%$. The returns of the other four Africa markets remained within the range of $40 \%$ - 55\% per annum. Kenyan market return remained below all four benchmark indices. The standard deviation as a measure of volatility, or risk, shows that the Zambian market is the most volatile, with annualized standard deviation of $30.15 \%$. This may be attributable to the fact that the equity market of Zambia is very new, and investors may be wary of its long-term survival. The Egyptian 
market is the second most volatile, with annualized standard deviation of $29.73 \%$ - this is likely attributable to the political uprisings in the country over the last few years. The South African markets come third with a standard deviation of $29.01 \%$. It is also noted that Tunisian markets have been the least volatile, with an annualized standard deviation of $11.34 \%$.

Table 1. Descriptive statistics

\begin{tabular}{|c|c|c|c|c|c|c|c|c|c|c|c|}
\hline & Mean & Std. dev. & Skewness & Excess & Normality & & & & & & \\
\hline Currency exchange rate & $(\%)$ & $(\%)$ & & Kurtosis & (p-value) & ADF & ARCH & $Q(15)$ & & & \\
\hline \multicolumn{12}{|l|}{ Panel A: Summary statistics } \\
\hline BRIC & 61.0 & 25.970 & -0.077 & 10.599 & $<0.001$ & $<0.001$ & $<0.001$ & 32.645 & & & \\
\hline Egypt & 47.1 & 29.726 & -1.777 & 98.202 & $<0.001$ & $<0.001$ & $<0.001$ & 68.249 & & & \\
\hline Emg Mkt. & 53.7 & 20.851 & -0.342 & 9.956 & $<0.001$ & $<0.001$ & $<0.001$ & 37.4 & & & \\
\hline Kenya & 13.0 & 26.155 & 11.248 & 657.171 & $<0.001$ & $<0.001$ & $<0.001$ & 18.631 & & & \\
\hline Mauritius & 50.8 & 13.062 & 0.246 & 16.628 & $<0.001$ & $<0.001$ & $<0.001$ & 39.647 & & & \\
\hline Morocco & 40.6 & 15.774 & -0.203 & 11.039 & $<0.001$ & $<0.001$ & $<0.001$ & 18.234 & & & \\
\hline S. Africa & 83.6 & 29.015 & -0.122 & 8.122 & $<0.001$ & $<0.001$ & $<0.001$ & 36.258 & & & \\
\hline Tunisia & 54.8 & 11.343 & 0.057 & 8.265 & $<0.001$ & $<0.001$ & $<0.001$ & 18.95 & & & \\
\hline Zambia & 101.7 & 30.154 & 0.728 & 12.623 & $<0.001$ & $<0.001$ & $<0.001$ & 32.074 & & & \\
\hline World & 23.3 & 17.406 & -0.171 & 9.799 & $<0.001$ & $<0.001$ & $<0.001$ & 27.942 & & & \\
\hline USA & 29.6 & 21.073 & -0.011 & 10.503 & $<0.001$ & $<0.001$ & $<0.001$ & 24.654 & & & \\
\hline $\begin{array}{c}\text { Panel B: Before crisis } \\
\text { correlations }\end{array}$ & BRIC & Emg Mkt. & USA & World & S. Africa & Nigeria & Kenya & Egypt & Morocco & Tunisia & Mauritius \\
\hline BRIC & 1.000 & & & & & & & & & & \\
\hline Egypt & 0.081 & 1.000 & & & & & & & & & \\
\hline Emg Mkt. & 0.827 & 0.104 & 1.000 & & & & & & & & \\
\hline Kenya & 0.065 & 0.002 & 0.056 & 1.000 & & & & & & & \\
\hline Mauritius & 0.039 & -0.017 & 0.027 & 0.046 & 1.000 & & & & & & \\
\hline Morocco & 0.023 & 0.077 & 0.034 & 0.001 & 0.026 & 1.000 & & & & & \\
\hline S. Africa & 0.326 & 0.042 & 0.408 & 0.021 & 0.024 & 0.060 & 1.000 & & & & \\
\hline Tunisia & -0.001 & 0.016 & 0.018 & 0.059 & 0.020 & 0.296 & 0.064 & 1.000 & & & \\
\hline Zambia & 0.023 & 0.016 & -0.014 & -0.016 & 0.015 & -0.022 & -0.015 & 0.017 & 1.000 & & \\
\hline World & 0.523 & 0.057 & 0.597 & 0.004 & 0.025 & 0.030 & 0.318 & 0.023 & 0.032 & 1.000 & \\
\hline USA & 0.362 & 0.007 & 0.367 & 0.004 & 0.011 & -0.048 & 0.150 & -0.076 & 0.045 & 0.874 & 1.000 \\
\hline $\begin{array}{c}\text { Panel C: Crisis period } \\
\text { correlations }\end{array}$ & BRIC & Emg Mkt. & USA & World & S. Africa & Nigeria & Kenya & Egypt & Morocco & Tunisia & Mauritius \\
\hline BRIC & 1.000 & & & & & & & & & & \\
\hline Egypt & 0.176 & 1.000 & & & & & & & & & \\
\hline Emg Mkt. & 0.963 & 0.193 & 1.000 & & & & & & & & \\
\hline Kenya & 0.164 & 0.111 & 0.183 & 1.000 & & & & & & & \\
\hline Mauritius & 0.225 & 0.099 & 0.239 & 0.172 & 1.000 & & & & & & \\
\hline Morocco & 0.387 & 0.108 & 0.409 & 0.144 & 0.194 & 1.000 & & & & & \\
\hline S. Africa & 0.767 & 0.151 & 0.812 & 0.155 & 0.174 & 0.436 & 1.000 & & & & \\
\hline Tunisia & 0.322 & 0.052 & 0.360 & 0.121 & 0.175 & 0.417 & 0.414 & 1.000 & & & \\
\hline Zambia & 0.135 & 0.053 & 0.169 & 0.200 & 0.160 & 0.037 & 0.153 & 0.051 & 1.000 & & \\
\hline World & 0.787 & 0.127 & 0.778 & 0.143 & 0.169 & 0.405 & 0.740 & 0.316 & 0.130 & 1.000 & \\
\hline USA & 0.619 & 0.067 & 0.568 & 0.059 & 0.065 & 0.229 & 0.483 & 0.128 & 0.052 & 0.901 & 1.000 \\
\hline
\end{tabular}


A careful examination of the skewness and kurtosis shows that the data is not normally distributed. As shown in the Table 1, all the countries' indices have excess kurtosis, emphasizing that the data exhibits fat tails. Some of the indices are skewed to the left, or to the negative, with the exception of Kenya, Zambia, Mauritius, and Tunisia that are skewed to the right, or to the positive. Practically this means that positive shocks are more prevalent than negative shocks on the Kenyan, Zambian, Mauritian, and the Tunisian equity markets. These features call for the use of non-linear models, and in this case we use the VAR-GARCH-BEKK model.

Furthermore, we can note that statistically speaking investors have a higher probability of reaping positive results on the average in the positively skewed markets, than on the markets with negative skewness. This is confirmed by the Jarque-Berra (JB) test for normality. The null hypothesis for JB test of normality is rejected for all the indices, meaning that the return distributions are non-normal.

The Adjusted Dickey Fuller (ADF) test was used to check the presence of unit root in the data while KPSS test was used to test for stationarity. As shown in Table 1, ADF statistics of all indices are statistically significant at the $1 \%$ level, meaning that the null hypothesis is rejected in favor of the alternate hypothesis of no unit root presence in the data. The KPSS test, on the other hand, has a null hypothesis of stationarity and as depicted in Table 1, all KPSS statistics were statistically insignificant, meaning that the data is stationary. "LB" in Table 1 represents the Ljung-Box Q-statistics for residual serial correlation up to the 15th order. The LB statistic shows that there is autocorrelation in returns for all the indices, and this signifies the presence of ARCH effects - this is confirmed by the ARCH-LM test. All the indices are statistically significant at $1 \%$ significance level, and have large values again signifying the presence of $\mathrm{ARCH}$ effects in the data, and hence the selection of the VAR-GARCH-BEKK model is justified.

Figure 1 shows that all the series under consideration exhibit some form of volatility clustering at some point of time. The MSCI benchmark index for the US, as shown in Figure 1, shows unusually high volatility clustering towards the end of the year 2008; this can be attributed to the sub-prime crisis events around that period.

WMI, EMI, and the MSCI BRIC index also show some spikes during the same period. Intuitively, it can be supposed from looking at the figure that, the African markets that are likely to be correlated with the world market, and the US market also exhibit high volatility clustering during the same time periods. Table 1 panel B shows the correlations between the time series. Zambian and Kenyan markets are the least correlated with all other markets and with both the WMI and EMI. The South African markets are not significantly correlated with the USMI, but more so with most of other considered markets and indices; this can be partially attributed to the fact that they are included in in the EMI. Within Africa, South Africa is highly correlated with the Tunisian, the Moroccan, the Egyptian, and the Mauritian markets. As neighbors in the North of Africa, Moroccan markets are highly correlated with the Tunisian markets, while both also correlate strongly with the EMI, the BRIC index, and to a smaller degree, with the WMI.

\section{Empirical Results}

The empirical results section presents the results of the study and also answers the research questions posed in the introduction part of this study. Among other things, this study examines, whether international linkages between the African, the US, and the World markets exist, after the African financial liberalization. It also examines the returns and volatility spillovers among thinly traded African equity markets and their international counterparts. Finally, the study establishes the potential of stock markets in Africa, to provide insights into portfolio diversification. The selected African markets are studied pairwise with each one of the four indices BRIC, EMI, WMI, and USMI. Hence a total of 28 pairs are studied using the VAR-GARCH-BEKK model.

First, the parameter $\beta$ in the mean equation, Eq. (1) is analyzed. The matrix $\boldsymbol{\beta}$ presents the return dynamics between the African stock markets and WMI, USMI, EMI, and the BRIC Market Index. The diagonal parameters $\boldsymbol{\beta} \mathbf{i i}$ and $\boldsymbol{\beta} \mathbf{j} \mathbf{j}$ depict the auto-correlation of returns. The off-diagonal parameters $\boldsymbol{\beta} \mathbf{i j}$ and $\boldsymbol{\beta} \mathbf{j i}$ depict the return spillovers across the markets. First four parameters, as depicted in the Tables $3-9$, present the matrix $\boldsymbol{\beta}$ in the mean equation. This part of the equation captures the linkages between the markets with respect to the returns. The pairwise models show that diagonal parameter $\beta$ ii that shows the autocorrelation within the market analysed is mostly significant in all markets (full sample) except for Tunisia, Morocco, and Zambia. This suggests that the returns of the South Africa, Kenya, Mauritius, and Egypt are dependent on the one-period lagged returns. However, the past returns of Tunisian, Moroccan, and Zambian markets do not statistically explain the current period returns. In other words, the current shocks in retuns within South Africa, Kenya, Mauritius, and Egypt will have a high influence on the one-period-ahead returns, within these markets, compared to the same effect in Tunisia, Morocco, and in Zambia. 
Table 2. South Africa

\begin{tabular}{|c|c|c|c|c|c|c|c|c|c|c|c|c|}
\hline \multicolumn{13}{|c|}{ Panel A: VAR(1)- GARCH(1. 1)-BEKK estimations } \\
\hline & \multicolumn{3}{|c|}{ SOUTH AFRICA - BRIC } & \multicolumn{3}{|c|}{ SOUTH AFRICA - EM } & \multicolumn{3}{|c|}{ SOUTH AFRICA - US } & \multicolumn{3}{|c|}{ SOUTH AFRICA - WORLD } \\
\hline & Full- & Pre- & Crisis- & Full- & Pre- & Crisis- & Full- & Pre- & Crisis- & Full- & Pre- & Crisis- \\
\hline & Sample & Crisis & Period & Sample & Crisis & Period & Sample & Crisis & Period & Sample & Crisis & Period \\
\hline Parameters & Coeff. & Coeff. & Coeff. & Coeff. & Coeff. & Coeff. & Coeff. & Coeff. & Coeff. & Coeff. & Coeff. & Coeff. \\
\hline $\boldsymbol{\beta}_{\mathrm{ii}}$ & $-0.166^{*}$ & $-0.142^{*}$ & $-0.171 *$ & $-0.225^{*}$ & $-0.194 *$ & $-0.118^{*}$ & $-0.249^{*}$ & $-0.243 *$ & $-0.194 *$ & $-0.346^{*}$ & $-0.316^{*}$ & -0.247 * \\
\hline $\boldsymbol{\beta}_{\mathrm{ij}}$ & $0.187 *$ & $0.162^{*}$ & $0.218^{*}$ & $0.076^{*}$ & 0.017 & $0.135^{*}$ & $0.566 *$ & $0.523^{*}$ & $0.504^{*}$ & $0.642 *$ & $0.632 *$ & $0.525^{*}$ \\
\hline $\boldsymbol{\beta}_{\mathrm{ji}}$ & 0.012 & 0.007 & 0.040 & $0.044^{*}$ & $0.035^{*}$ & $0.132^{*}$ & $0.012 *$ & 0.007 & $0.056^{*}$ & 0.005 & 0.004 & 0.004 \\
\hline $\boldsymbol{\beta}_{\mathrm{jj}}$ & $0.034 *$ & $0.042^{*}$ & -0.019 & $-0.092 *$ & $-0.072 *$ & $-0.163 *$ & $-0.072 *$ & $-0.064 *$ & $-0.108 *$ & $0.108^{*}$ & $0.130^{*}$ & $0.099 *$ \\
\hline$\omega_{\mathrm{ii}}$ & $0.808^{*}$ & $0.930^{*}$ & -0.085 & $0.972^{*}$ & $0.869^{*}$ & -0.005 & $1.119^{*}$ & $1.150^{*}$ & 0.079 & $1.103^{*}$ & $1.117 *$ & $0.073 *$ \\
\hline$\omega_{i j}$ & $-0.235^{*}$ & $-0.250^{*}$ & $0.131^{*}$ & -0.056 & $-0.270 *$ & $-0.155^{*}$ & $0.051^{*}$ & $0.053^{*}$ & $-0.147 *$ & $0.038^{*}$ & $0.042 *$ & $-0.108^{*}$ \\
\hline$\omega_{\mathrm{jj}}$ & 0.000 & 0.000 & 0.000 & $-0.252 *$ & $0.258^{*}$ & -0.012 & $0.069^{*}$ & 0.000 & 0.000 & 0.000 & 0.000 & 0.000 \\
\hline$\gamma_{\mathrm{ii}}$ & $1.071^{*}$ & $1.210^{*}$ & 0.037 & $1.098^{*}$ & $1.244^{*}$ & $0.148^{*}$ & $1.069^{*}$ & $1.200^{*}$ & $0.226^{*}$ & $1.052 *$ & $1.068^{*}$ & $0.252 *$ \\
\hline$\gamma_{i j}$ & $0.029^{*}$ & $0.060^{*}$ & $-0.133^{*}$ & $-0.136^{*}$ & $-0.141^{*}$ & 0.014 & $-0.027 *$ & $-0.021 *$ & $-0.065^{*}$ & $-0.059^{*}$ & $-0.039^{*}$ & -0.053 \\
\hline$\gamma_{\mathrm{ji}}$ & $-0.863 *$ & $-0.912^{*}$ & $0.301 *$ & -0.040 & -0.071 & $0.229^{*}$ & 0.051 & $0.223^{*}$ & 0.010 & $0.155^{*}$ & $0.602 *$ & -0.040 \\
\hline$\gamma_{\mathrm{jj}}$ & $0.279 *$ & $0.255^{*}$ & $0.365^{*}$ & $0.341^{*}$ & $0.335^{*}$ & $0.272 *$ & $0.258^{*}$ & $0.202^{*}$ & $0.386^{*}$ & $0.272^{*}$ & $0.218^{*}$ & $0.333^{*}$ \\
\hline$\delta_{\mathrm{ii}}$ & $0.393 *$ & $0.308^{*}$ & $1.091 *$ & $0.272^{*}$ & $0.186^{*}$ & $1.070^{*}$ & $0.432 *$ & $0.348^{*}$ & $0.972 *$ & $0.321^{*}$ & $0.310^{*}$ & $0.962^{*}$ \\
\hline$\delta_{\mathrm{ij}}$ & -0.010 & $-0.027^{*}$ & $0.161^{*}$ & $0.098^{*}$ & $0.099^{*}$ & $0.103^{*}$ & $0.016^{*}$ & $0.014^{*}$ & $0.027^{*}$ & $0.039^{*}$ & $0.026^{*}$ & $0.022^{*}$ \\
\hline$\delta_{\mathrm{ji}}$ & $0.498 *$ & $0.489^{*}$ & $-0.212^{*}$ & $0.562 *$ & $0.706^{*}$ & $-0.185^{*}$ & $0.178^{*}$ & $0.121 *$ & 0.000 & $0.541 *$ & $0.406^{*}$ & 0.021 \\
\hline$\delta_{\mathrm{jj}}$ & $0.952 *$ & $0.959^{*}$ & $0.814^{*}$ & $0.858^{*}$ & $0.843 *$ & $0.849^{*}$ & $0.957^{*}$ & $0.973^{*}$ & $0.912 *$ & $0.926^{*}$ & $0.951 *$ & $0.930^{*}$ \\
\hline \multicolumn{13}{|c|}{ Panel B: Diagnostic tests } \\
\hline LogLik & -15153 & -10804 & -4237 & -14914 & -10554 & -4062 & -14165 & -9897 & -4055 & -13124 & -9101 & -3739 \\
\hline $\mathrm{LB}_{\mathrm{i}}$ & 18.009 & 17.66 & 22.32 & 35.188 & 27.31 & 22.04 & 18.817 & 15.52 & 24.26 & 29.379 & 21.69 & 24.4 \\
\hline $\mathrm{LB}_{\mathrm{j}}$ & 45.806 & 42.29 & 34.49 & 64.948 & 61.12 & 34.25 & 28.931 & 27.29 & 20.66 & 36.029 & 30.69 & 18.96 \\
\hline $\mathrm{LB}^{2}{ }_{\mathrm{i}}$ & 0.144 & 0.164 & 24.95 & 0.117 & 0.133 & 26.98 & 0.109 & 0.148 & 36.98 & 0.163 & 0.2 & 38.76 \\
\hline $\mathrm{LB}^{2}{ }_{\mathrm{j}}$ & 25.337 & 22.7 & 31.92 & 31.124 & 36.31 & 28.67 & 44.593 & 29.03 & 38.65 & 36.612 & 32.39 & 38.75 \\
\hline
\end{tabular}

The off-diagonal parameters $\beta \mathrm{ij}$ and $\beta \mathrm{ji}$, which reveal the return spillovers across the markets, are as follows: South Africa receives past returns spillover from the BRIC group of countries. South Africa is also influenced by past innovations from EMI, and influenced massively by USMI past innovations. More so, the past innovations also from the WMI influence the South African market returns. The evidence of returns spillover between South Africa, WMI, and USMI indicates that there are strong linkages between these markets. Conversely, the South African market exports past return innovations to the EMI, emphasizing that there is a bi-directional relationship between the South African markets and EMI. The size of the South Africa market, with respect to market capitalization and liquidity in Africa and the world at large, explains the high level of return spillover between the South Africa, US markets and the World markets.

At the $10 \%$ significance level, Tunisia receives a meager amount of past innovations from the BRIC group of countries. Tunisia receives nothing from the rest of the markets. It however, exports past innovation to the USMI. This is an indication that the Tunisian market is still very much segmented and isolated from the other world markets. The Egyptian markets, as one of the major markets in Africa, with respect to market capitalization 
receive past innovation from the EMI, USMI, WMI, and the BRIC Market Index, but do not export shocks to any of the markets under consideration. It can be seen that the Egyptian markets are influenced highly by both USMI and WMI, signaling the presence of integration between these markets. The Moroccan market also receives past returns spillover from BRIC Markets Index, EMI, and USMI.

Table 3. Egypt

\begin{tabular}{|c|c|c|c|c|c|c|c|c|c|c|c|c|}
\hline \multicolumn{13}{|c|}{ Panel A: VAR(1)- GARCH(1. 1)-BEKK estimations } \\
\hline & \multicolumn{3}{|c|}{ EGYPT - BRIC } & \multicolumn{3}{|c|}{ EGYPT - EM } & \multicolumn{3}{|c|}{ EGYPT - US } & \multicolumn{3}{|c|}{ EGYPT - WORLD } \\
\hline & Full- & Pre- & Crisis- & Full- & Pre- & Crisis- & Full- & Pre- & Crisis- & Full- & Pre- & Crisis- \\
\hline & Sample & Crisis & Period & Sample & Crisis & Period & Sample & Crisis & Period & Sample & Crisis & Period \\
\hline Parameters & Coeff. & Coeff. & Coeff. & Coeff. & Coeff. & Coeff. & Coeff. & Coeff. & Coeff. & Coeff. & Coeff. & Coeff. \\
\hline$\beta_{\mathrm{ii}}$ & $-0.069 *$ & 0.003 & $-0.206^{*}$ & $-0.070 *$ & 0.001 & -0.054 & $-0.078^{*}$ & -0.004 & -0.049 & $-0.069 *$ & -0.016 & -0.047 \\
\hline $\boldsymbol{\beta}_{\mathrm{ij}}$ & $0.060^{*}$ & $0.061 *$ & $0.744^{*}$ & $0.075^{*}$ & $0.075^{*}$ & $0.154^{*}$ & $0.085^{*}$ & $0.073^{*}$ & $0.141^{*}$ & $0.110^{*}$ & $0.103 *$ & $0.356^{*}$ \\
\hline$\beta_{\mathrm{ji}}$ & 0.002 & 0.025 & -0.004 & -0.003 & 0.017 & -0.009 & 0.001 & 0.004 & -0.011 & 0.004 & 0.003 & 0.011 \\
\hline $\boldsymbol{\beta}_{\mathrm{jj}}$ & 0.013 & 0.010 & 0.019 & 0.009 & 0.027 & 0.021 & $-0.052 *$ & $-0.058 *$ & -0.036 & $0.131^{*}$ & $0.145^{*}$ & -0.044 \\
\hline$\omega_{\mathrm{ii}}$ & $0.118^{*}$ & $0.273 *$ & $0.308^{*}$ & $0.119 *$ & $0.273^{*}$ & $1.359^{*}$ & $-0.031 *$ & $0.235^{*}$ & $1.354 *$ & $0.048^{*}$ & $0.208 *$ & $1.360^{*}$ \\
\hline$\omega_{\mathrm{ij}}$ & $0.055^{*}$ & 0.057 & -0.009 & $0.066^{*}$ & $0.087^{*}$ & $0.076^{*}$ & $0.093^{*}$ & -0.012 & $0.116^{*}$ & $0.086^{*}$ & -0.006 & -0.021 \\
\hline$\omega_{\mathrm{jj}}$ & $-0.209 *$ & $0.260 *$ & $0.134^{*}$ & $0.211^{*}$ & $0.275^{*}$ & $-0.114 *$ & 0.000 & $0.064^{*}$ & $-0.111^{*}$ & 0.000 & $0.059 *$ & $0.134^{*}$ \\
\hline$\gamma_{\mathrm{ii}}$ & $0.197 *$ & $0.331 *$ & $0.793^{*}$ & $0.197^{*}$ & $0.363^{*}$ & $0.409^{*}$ & $0.192 *$ & $0.388^{*}$ & $0.428 *$ & $0.180^{*}$ & $0.397 *$ & $0.388^{*}$ \\
\hline$\gamma_{i j}$ & 0.004 & -0.007 & $0.045^{*}$ & 0.005 & 0.042 & 0.018 & $0.007 *$ & 0.010 & $0.026^{*}$ & -0.006 & 0.006 & -0.011 \\
\hline$\gamma_{j i}$ & -0.000 & -0.015 & $-1.134 *$ & 0.002 & $-0.040 *$ & $-0.066^{*}$ & $-0.069 *$ & $-0.113 *$ & $-0.133^{*}$ & $0.076^{*}$ & $-0.150^{*}$ & -0.054 \\
\hline$\gamma_{j j}$ & $0.297^{*}$ & $0.291 *$ & $0.167^{*}$ & $0.297 *$ & $0.278^{*}$ & $0.269^{*}$ & $0.238^{*}$ & $0.179^{*}$ & $0.261^{*}$ & $0.259^{*}$ & $0.185^{*}$ & $0.321^{*}$ \\
\hline$\delta_{\mathrm{ii}}$ & $0.981^{*}$ & $0.912 *$ & $0.762^{*}$ & $0.981^{*}$ & $0.902^{*}$ & $0.835^{*}$ & $0.983^{*}$ & $0.896^{*}$ & $0.831 *$ & $0.985^{*}$ & $0.900 *$ & $0.842^{*}$ \\
\hline$\delta_{i j}$ & 0.000 & -0.002 & $-0.014 *$ & 0.001 & -0.027 & -0.013 & -0.000 & -0.003 & $-0.016^{*}$ & $0.001^{*}$ & -0.002 & 0.006 \\
\hline$\delta_{\mathrm{ji}}$ & -0.001 & 0.001 & $0.175^{*}$ & -0.003 & $0.009^{*}$ & $0.032^{*}$ & $0.018^{*}$ & $0.022^{*}$ & $0.038^{*}$ & $-0.026^{*}$ & $0.031 *$ & 0.034 \\
\hline$\delta_{\mathrm{jj}}$ & $0.947^{*}$ & $0.944 *$ & $0.975^{*}$ & $0.945^{*}$ & $0.941 *$ & $0.963^{*}$ & $0.968^{*}$ & $0.982^{*}$ & $0.963 *$ & $0.963^{*}$ & $0.980 *$ & $0.942 *$ \\
\hline \multicolumn{13}{|c|}{ Panel B: Diagnostic tests } \\
\hline LogLik & -14336 & -7088 & -4783 & -14016 & -8905 & -5284 & -12820 & -8655 & -5210 & -12036 & -7752 & -4880 \\
\hline $\mathrm{LB}_{\mathrm{i}}$ & 36.683 & 41.25 & 17.1 & 35.659 & 40.8 & 20.885 & 49.935 & 50.26 & 20 & 41.337 & 48.62 & 18.91 \\
\hline $\mathrm{LB}_{\mathrm{j}}$ & 47.245 & 44.54 & 26.53 & 44.304 & 42.24 & 33.139 & 26.682 & 26.12 & 33.57 & 33.103 & 28.13 & 17.39 \\
\hline $\mathrm{LB}^{2}{ }_{\mathrm{i}}$ & 0.481 & 0.491 & 0.463 & 0.485 & 0.547 & 0.2144 & 0.599 & 1.002 & 0.221 & 0.710 & 1.227 & 0.218 \\
\hline $\mathrm{LB}^{2}{ }_{\mathrm{j}}$ & 24.078 & 25.01 & 74.81 & 28.008 & 30.97 & 24.478 & 56.395 & 45.1 & 26.54 & 43.509 & 65.79 & 40.02 \\
\hline
\end{tabular}

The returns of the Kenya market is influenced by the return past innovations from the EMI, USMI, and WMI. The Kenyan market can be said to be highly integrated with the US markets and the World markets. Even though the Kenyan markets do not receive past innovations from the BRIC, it exports to all the four markets. Mauritian markets receive return past innovations from the BRIC, EMI, USMI, and WMI. It however, statistically speaking exports past return innovation to the World markets. Mauritian stock markets are to an extent integrated with the World markets, as well, as the US markets. Finally, a unidirectional relationship exists between Zambian and all the benchmark markets; Zambian markets receive shocks from all the markets, but exports to none of them. In 
summary, South Africa, Egypt, Morocco and Kenya seem to be highly integrated with the US and World markets, while Zambia and Mauritius are only weakly integrated with these markets. Tunisia seems to be segmented from the US and the World markets.

Next, the time-varying variance-covariance is analyzed and attention is focused on the parameters $\gamma$ and $\boldsymbol{\delta}$ shown in the Table $2-8$. These parameters capture the pair-wise volatility dynamics within, and across the markets. The diagonal estimates in matrix $\boldsymbol{\gamma}$ show the ARCH effects, whereas the diagonal estimates in matrix $\boldsymbol{\delta}$ capture the GARCH effect. The off-diagonal estimates, on the other hand, present the cross-market shock transmission and volatility spillovers across the markets. The estimated diagonal parameters, $\gamma \mathbf{i i i}, \gamma \mathbf{j j}$ and $\boldsymbol{\delta} \mathbf{i i}, \boldsymbol{\delta} \mathbf{j} \mathbf{j}$, as depicted in Tables 3-9, show that for all studied markets all the studied parameters are statistically significant, and implying that lagged shocks and volatility have a major impact on the conditional variance of all the seven African markets, examined in this study.

Table 4. Kenya

\begin{tabular}{|c|c|c|c|c|c|c|c|c|c|c|c|c|}
\hline \multicolumn{13}{|c|}{ Panel A: VAR(1)- GARCH(1. 1)-BEKK estimations } \\
\hline & \multicolumn{3}{|c|}{ KENYA - BRIC } & \multicolumn{3}{|c|}{ KENYA - EM } & \multicolumn{3}{|c|}{ KENYA - US } & \multicolumn{3}{|c|}{ KENYA - WORLD } \\
\hline & Full- & Pre- & Crisis- & Full- & Pre- & Crisis- & Full- & Pre- & Crisis- & Full- & Pre- & Crisis- \\
\hline & Sample & Crisis & Period & Sample & Crisis & Period & Sample & Crisis & Period & Sample & Crisis & Period \\
\hline Parameters & Coeff. & Coeff. & Coeff. & Coeff. & Coeff. & Coeff. & Coeff. & Coeff. & Coeff. & Coeff. & Coeff. & Coeff. \\
\hline $\boldsymbol{\beta}_{\mathrm{ii}}$ & $0.329^{*}$ & $0.310^{*}$ & $0.381^{*}$ & $0.331^{*}$ & $0.310^{*}$ & $0.378 *$ & $0.261 *$ & $0.228^{*}$ & $0.381 *$ & $0.230^{*}$ & $0.206^{*}$ & $0.395 *$ \\
\hline $\boldsymbol{\beta}_{\mathrm{ij}}$ & -0.008 & -0.014 & $0.033^{*}$ & $-0.046^{*}$ & $-0.065^{*}$ & $0.026^{*}$ & $-0.160 *$ & $-0.211 *$ & $0.053^{*}$ & $-0.241 *$ & $-0.304 *$ & $0.055^{*}$ \\
\hline $\boldsymbol{\beta}_{\mathrm{ji}}$ & $-0.046^{*}$ & -0.017 & $-0.101 *$ & $-0.071 *$ & $-0.047 *$ & $-0.099 *$ & $-0.033^{*}$ & -0.010 & $-0.076 *$ & -0.012 & 0.003 & $-0.088^{*}$ \\
\hline $\boldsymbol{\beta}_{\mathrm{jj}}$ & 0.006 & 0.006 & 0.010 & $-0.047 *$ & $-0.036^{*}$ & $-0.053 *$ & $-0.175^{*}$ & $-0.176^{*}$ & $-0.059 *$ & -0.001 & 0.021 & $0.099 *$ \\
\hline$\omega_{\mathrm{ii}}$ & $0.540^{*}$ & $0.554^{*}$ & $0.184 *$ & $0.499 *$ & $0.503 *$ & $0.162^{*}$ & $0.506^{*}$ & $0.547 *$ & $0.196 *$ & $0.559^{*}$ & $0.573^{*}$ & $0.169 *$ \\
\hline$\omega_{\mathrm{ij}}$ & $0.085^{*}$ & $0.165^{*}$ & 0.033 & 0.044 & $0.150 *$ & 0.038 & -0.011 & 0.010 & $-0.099 *$ & 0.014 & $0.053^{*}$ & -0.082 \\
\hline$\omega_{\mathrm{jj}}$ & 0.033 & 0.000 & $0.131^{*}$ & 0.043 & 0.000 & 0.107 & 0.049 & 0.000 & 0.000 & $0.058^{*}$ & 0.000 & 0.000 \\
\hline$\gamma_{\mathrm{ii}}$ & $0.560^{*}$ & $0.658^{*}$ & $0.297^{*}$ & $0.523^{*}$ & $0.624 *$ & $0.284 *$ & $0.662 *$ & $0.800^{*}$ & $0.237 *$ & $0.806^{*}$ & $0.944^{*}$ & $0.229 *$ \\
\hline$\gamma_{i j}$ & $-0.068 *$ & $-0.062 *$ & 0.021 & $-0.106^{*}$ & $-0.109^{*}$ & -0.040 & $-0.122^{*}$ & $-0.094^{*}$ & $-0.203^{*}$ & $-0.084^{*}$ & $-0.062 *$ & $-0.202^{*}$ \\
\hline$\gamma_{\mathrm{ji}}$ & $0.373^{*}$ & $0.416^{*}$ & $0.087^{*}$ & $0.366^{*}$ & $0.405^{*}$ & $0.087^{*}$ & $0.459^{*}$ & $0.446^{*}$ & $0.190^{*}$ & $0.535^{*}$ & $0.545^{*}$ & $0.182 *$ \\
\hline$\gamma_{\mathrm{jj}}$ & $0.178^{*}$ & $0.195^{*}$ & $0.249^{*}$ & $0.114^{*}$ & $0.134 *$ & $0.245^{*}$ & $0.156^{*}$ & $0.152^{*}$ & $0.203^{*}$ & $0.216^{*}$ & $0.220^{*}$ & $0.185^{*}$ \\
\hline$\delta_{\text {ii }}$ & $0.354^{*}$ & $0.315^{*}$ & $0.899 *$ & $0.433^{*}$ & $0.404 *$ & $0.915^{*}$ & $0.451 *$ & $0.402^{*}$ & $0.876^{*}$ & $0.339^{*}$ & $0.321^{*}$ & $0.904 *$ \\
\hline$\delta_{\mathrm{ij}}$ & $0.183^{*}$ & $0.111^{*}$ & $0.101^{*}$ & $0.254^{*}$ & $0.194 *$ & $0.107 *$ & $0.123^{*}$ & $0.073^{*}$ & $0.247 *$ & $0.076^{*}$ & $0.042^{*}$ & $0.237 *$ \\
\hline$\delta_{\mathrm{ji}}$ & $-0.065^{*}$ & $-0.097 *$ & $-0.034 *$ & $-0.056^{*}$ & $-0.095^{*}$ & $-0.035^{*}$ & $-0.041 *$ & $-0.041 *$ & $-0.072 *$ & $-0.049 *$ & $-0.094 *$ & $-0.078^{*}$ \\
\hline$\delta_{\mathrm{jj}}$ & $0.966^{*}$ & $0.968^{*}$ & $0.959^{*}$ & $0.966^{*}$ & $0.970 *$ & $0.958 *$ & $0.971 *$ & $0.981^{*}$ & $0.944 *$ & $0.962 *$ & $0.969^{*}$ & $0.942 *$ \\
\hline \multicolumn{13}{|c|}{ Panel B: Diagnostic tests } \\
\hline LogLik & -12431 & -8789 & -3580 & -12010 & -8440 & -3503 & -10966 & -7668 & -3167 & -10375 & -7091 & -3089 \\
\hline $\mathrm{LB}_{\mathrm{i}}$ & 50.635 & 46.82 & 41.43 & 53.764 & 52.03 & 40.98 & 63.233 & 53.16 & 38.02 & 70.899 & 58.66 & 37.42 \\
\hline $\mathrm{LB}_{\mathrm{j}}$ & 54.291 & 50.52 & 32.28 & 68.923 & 64.75 & 33.57 & 86.853 & 71.19 & 17.18 & 115.938 & 84.21 & 19.06 \\
\hline $\mathrm{LB}^{2}{ }_{\mathrm{i}}$ & 0.753 & 0.727 & 19.64 & 1.253 & 0.972 & 18.25 & 0.803 & 0.766 & 26.05 & 0.804 & 0.861 & 23.95 \\
\hline $\mathrm{LB}^{2}{ }_{\mathrm{j}}$ & 38.611 & 42.1 & 24.93 & 60.477 & 57.56 & 24.01 & 51.643 & 31.9 & 32.79 & 30.414 & 20.2 & 29.09 \\
\hline
\end{tabular}

The off-diagonal estimates $\gamma \mathbf{i j}$ and $\gamma \mathbf{j i}$ present the cross-markets shock transmission between each of the pairs. As 
shown in Tables 3-9, South Africa receives shock transmission from all MSCI indices under consideration, notably from the USMI and from the WMI. We found a bi-directional relationship between South Africa and WMI, as well as the BRIC markets. Egypt is integrated with the US market in that it receives shocks from the US markets and exports shocks to the US and into the World Markets. Kenyan markets, like the South African markets, exhibit a very strong level of integration with all the indices in the study and especially with the USMI and the WMI and receive shock spillover from all these markets. It also exports shock volatility to all the benchmark markets under consideration. Shock-transmission between the Tunisian market and the studied market indices indicates that the Tunisian market is highly segmented from the US and the World markets. Moroccan markets also seem to be rather segmented from the US and the World markets. Zambian market exhibits traits that identify it to be segmented from the WMI, however with BRIC it shows the existence of a bi-directional relation. Finally, Mauritian markets, mainly export shocks to US and World markets; Mauritius is thereby less integrated with the WMI and USMI.

Table 5. Mauritius

\begin{tabular}{|c|c|c|c|c|c|c|c|c|c|c|c|c|}
\hline \multicolumn{13}{|c|}{ Panel A: VAR(1)- GARCH(1. 1)-BEKK estimations } \\
\hline & \multicolumn{3}{|c|}{ MAURITIUS - BRIC } & \multicolumn{3}{|c|}{ MAURITIUS - EM } & \multicolumn{3}{|c|}{ MAURITIUS - US } & \multicolumn{3}{|c|}{ MAURITIUS - WORLD } \\
\hline & Full- & Pre- & Crisis- & Full- & Pre- & Crisis- & Full- & Pre- & Crisis- & Full- & Pre- & Crisis- \\
\hline & Sample & Crisis & Period & Sample & Crisis & Period & Sample & Crisis & Period & Sample & Crisis & Period \\
\hline Parameters & Coeff. & Coeff. & Coeff. & Coeff. & Coeff. & Coeff. & Coeff. & Coeff. & Coeff. & Coeff. & Coeff. & Coeff. \\
\hline $\boldsymbol{\beta}_{\mathrm{ii}}$ & $-0.033^{*}$ & -0.012 & $-0.091 *$ & $-0.033^{*}$ & -0.016 & $-0.112^{*}$ & $-0.028^{*}$ & -0.003 & $-0.089^{*}$ & -0.026 & -0.006 & $-0.097^{*}$ \\
\hline$\beta_{\mathrm{ij}}$ & $0.021 *$ & $0.010^{*}$ & $0.117 *$ & $0.026^{*}$ & $0.012^{*}$ & $0.119^{*}$ & $0.027 *$ & 0.006 & $0.158^{*}$ & $0.055^{*}$ & $0.021 *$ & $0.205^{*}$ \\
\hline$\beta_{\mathrm{ji}}$ & 0.006 & $0.064^{*}$ & -0.031 & 0.001 & 0.045 & $-0.060^{*}$ & -0.021 & 0.007 & $-0.067^{*}$ & $-0.025^{*}$ & -0.007 & $-0.053^{*}$ \\
\hline $\boldsymbol{\beta}_{\mathrm{jj}}$ & 0.004 & 0.012 & 0.032 & -0.009 & 0.016 & $-0.054 *$ & $-0.049^{*}$ & $-0.040^{*}$ & $-0.088^{*}$ & $0.124 *$ & $0.147^{*}$ & $0.088^{*}$ \\
\hline$\omega_{\mathrm{ii}}$ & $0.108 *$ & $0.109^{*}$ & $0.228^{*}$ & $0.107^{*}$ & $0.098^{*}$ & $0.235^{*}$ & $0.106^{*}$ & $0.118^{*}$ & $0.194^{*}$ & $0.118^{*}$ & $0.113 *$ & $0.146^{*}$ \\
\hline$\omega_{\mathrm{ij}}$ & -0.006 & 0.027 & -0.013 & 0.012 & 0.055 & -0.059 & -0.010 & 0.025 & $-0.077^{*}$ & -0.009 & 0.013 & $-0.115^{*}$ \\
\hline$\omega_{\mathrm{jj}}$ & $0.205^{*}$ & $0.251^{*}$ & 0.000 & $0.206^{*}$ & $0.264^{*}$ & $-0.111 *$ & $0.103^{*}$ & $0.074 *$ & $-0.125^{*}$ & $0.081 *$ & $0.074 *$ & $0.112^{*}$ \\
\hline$\gamma_{\mathrm{ii}}$ & $0.395^{*}$ & $0.388^{*}$ & $0.331^{*}$ & $0.397^{*}$ & $0.371^{*}$ & $0.455^{*}$ & $0.391^{*}$ & $0.416^{*}$ & $0.371^{*}$ & $0.419^{*}$ & $0.400 *$ & $0.301 *$ \\
\hline$\gamma_{i j}$ & 0.032 & 0.041 & $0.139^{*}$ & $0.047^{*}$ & $0.065^{*}$ & 0.028 & -0.004 & $0.035^{*}$ & $-0.149 *$ & -0.003 & 0.014 & -0.036 \\
\hline$\gamma_{\mathrm{ji}}$ & 0.009 & 0.006 & $-0.080^{*}$ & $0.012^{*}$ & $0.011^{*}$ & $0.091^{*}$ & $0.017 *$ & 0.013 & $0.157^{*}$ & $0.032 *$ & 0.017 & -0.031 \\
\hline$\gamma_{j j}$ & $0.261 *$ & $0.274 *$ & $0.282^{*}$ & $0.259^{*}$ & $0.277^{*}$ & $0.232 *$ & $0.232 *$ & $0.199 *$ & $0.216^{*}$ & $0.224 *$ & $0.214^{*}$ & $0.290 *$ \\
\hline$\delta_{\mathrm{ii}}$ & $0.921 *$ & $0.920^{*}$ & $0.886^{*}$ & $0.921^{*}$ & $0.928^{*}$ & $0.863^{*}$ & $0.923 *$ & $0.908^{*}$ & $0.899^{*}$ & $0.910^{*}$ & $0.914^{*}$ & $0.946^{*}$ \\
\hline$\delta_{\mathrm{ij}}$ & -0.003 & -0.011 & $-0.256^{*}$ & -0.006 & -0.016 & 0.025 & 0.006 & -0.012 & $0.075^{*}$ & 0.006 & -0.003 & $0.021 *$ \\
\hline$\delta_{\mathrm{ji}}$ & -0.002 & -0.002 & $0.095^{*}$ & $-0.004 *$ & $-0.005^{*}$ & $-0.018 *$ & $-0.003 *$ & $-0.004^{*}$ & $-0.031^{*}$ & $-0.007^{*}$ & -0.005 & 0.013 \\
\hline$\delta_{\mathrm{jj}}$ & $0.958 *$ & $0.950^{*}$ & $0.960^{*}$ & $0.957^{*}$ & $0.944^{*}$ & $0.966^{*}$ & $0.969^{*}$ & $0.977^{*}$ & $0.957^{*}$ & $0.971^{*}$ & $0.973^{*}$ & $0.947^{*}$ \\
\hline \multicolumn{13}{|c|}{ Panel B: Diagnostic tests } \\
\hline LogLik & -11637 & -7690 & -4007 & -11332 & -7458 & -3902 & -10146 & -6562 & -3588 & -9406 & -5911.7 & -3501 \\
\hline $\mathrm{LB}_{\mathrm{i}}$ & 195.137 & 150.3 & 56.95 & 195.260 & 152.82 & 67.096 & 192.885 & 147.5 & 59.41 & 186.128 & 145.78 & 56.306 \\
\hline $\mathrm{LB}_{\mathrm{j}}$ & 48.707 & 43.1 & 33.81 & 47.802 & 43.052 & 32.603 & 26.536 & 24.88 & 17.32 & 34.223 & 28.247 & 18.581 \\
\hline $\mathrm{LB}_{\mathrm{i}}^{2}$ & 47.780 & 47.85 & 35.17 & 47.892 & 48.192 & 15.591 & 52.970 & 50.76 & 22.17 & 49.653 & 49.08 & 26.925 \\
\hline $\mathrm{LB}^{2}{ }_{\mathrm{j}}$ & 41.069 & 30.69 & 33.52 & 44.949 & 33.751 & 26.839 & 72.508 & 34.11 & 86.82 & 81.639 & 40.61 & 37.749 \\
\hline
\end{tabular}

Further, we present the off-diagonal estimates $\delta \mathrm{ij}$ and $\delta \mathrm{ji}$, candidates for the volatility spillovers between the 
pairs. In the corresponding Tables 3-9, it can be seen that the direction of movement between the shocks and volatility spillovers between the markets are almost the same, but they have different effect sizes. South African markets receive volatility spillover from three of the four major indices, but not from the BRIC index and transmit volatility spillovers to all the four markets. Egypt receives volatility spillovers from the World markets and exports them to the US markets. Kenya receives volatility spillovers from all the markets and exports spillovers to all the markets, underscoring a very high level of integration with the World and the US. Tunisia, a segmented market, exports volatility spillovers to none of the markets and receives no effects from the other markets - this is the same to some extent with Morocco and Zambia. Mauritian markets only export volatility spillovers to the other markets, without receiving any effects back.

The results can be summarized by observing that out of the seven markets studied, South Africa, Kenya, and Egypt are very integrated with the US and the World markets. On the other hand Tunisia, Morocco and Zambia exhibit traits of high level segmentation from the world and US markets. Further, a very special case exists with respect to Mauritius in that it exports volatility to all the markets under consideration but receives none back which makes it difficult to classify as segmented or integrated.

Table 6. Morocco

Panel A: VAR(1)- GARCH(1. 1)-BEKK estimations

\begin{tabular}{|c|c|c|c|c|c|c|c|c|c|c|c|c|}
\hline & \multicolumn{3}{|c|}{ MOROCCO - BRIC } & \multicolumn{3}{|c|}{ MOROCCO - EM } & \multicolumn{3}{|c|}{ MOROCCO - US } & \multicolumn{3}{|c|}{ MOROCCO - WORLD } \\
\hline & $\begin{array}{l}\text { Full- } \\
\text { Sample }\end{array}$ & $\begin{array}{l}\text { Pre- } \\
\text { Crisis }\end{array}$ & $\begin{array}{l}\text { Crisis- } \\
\text { Period }\end{array}$ & $\begin{array}{c}\text { Full- } \\
\text { Sample }\end{array}$ & $\begin{array}{c}\text { Pre- } \\
\text { Crisis }\end{array}$ & $\begin{array}{l}\text { Crisis- } \\
\text { Period }\end{array}$ & $\begin{array}{c}\text { Full- } \\
\text { Sample }\end{array}$ & $\begin{array}{c}\text { Pre- } \\
\text { Crisis }\end{array}$ & $\begin{array}{l}\text { Crisis- } \\
\text { Period }\end{array}$ & $\begin{array}{c}\text { Full- } \\
\text { Sample }\end{array}$ & $\begin{array}{l}\text { Pre- } \\
\text { Crisis }\end{array}$ & $\begin{array}{l}\text { Crisis- } \\
\text { Period }\end{array}$ \\
\hline Parameters & Coeff. & Coeff. & Coeff. & Coeff. & Coeff. & Coeff. & Coeff. & Coeff. & Coeff. & Coeff. & Coeff. & Coeff. \\
\hline $\boldsymbol{\beta}_{\mathrm{ii}}$ & -0.012 & 0.010 & 0.000 & -0.016 & -0.016 & 0.005 & -0.004 & -0.003 & -0.018 & -0.008 & -0.006 & -0.013 \\
\hline$\beta_{\mathrm{ij}}$ & $0.030 *$ & $0.037^{*}$ & -0.003 & $0.033^{*}$ & 0.012 & $-0.021 *$ & $0.031^{*}$ & $0.006^{*}$ & 0.079 & $0.036^{*}$ & $0.021 *$ & 0.023 \\
\hline$\beta_{\mathrm{ji}}$ & 0.018 & 0.022 & 0.001 & 0.007 & 0.045 & 0.041 & $0.034^{*}$ & 0.007 & 0.038 & 0.012 & -0.007 & 0.007 \\
\hline $\boldsymbol{\beta}_{\mathrm{jj}}$ & 0.012 & 0.006 & $-0.002 *$ & 0.012 & $0.016^{*}$ & $-0.062 *$ & $-0.061^{*}$ & -0.040 & -0.071 & $0.127^{*}$ & $0.147 *$ & $0.093^{*}$ \\
\hline$\omega_{\mathrm{ii}}$ & $0.327^{*}$ & $0.490 *$ & $0.612 *$ & $0.355^{*}$ & $0.098^{*}$ & $0.132^{*}$ & $0.313^{*}$ & $0.118^{*}$ & $0.143^{*}$ & $0.309^{*}$ & $0.113 *$ & $0.137 *$ \\
\hline$\omega_{\mathrm{ij}}$ & -0.001 & 0.043 & -0.043 & -0.006 & 0.055 & 0.117 & -0.026 & 0.025 & -0.015 & -0.018 & 0.013 & 0.006 \\
\hline$\omega_{\mathrm{jj}}$ & $0.206^{*}$ & $0.243^{*}$ & 0.000 & $0.213^{*}$ & $0.264^{*}$ & $-0.097^{*}$ & $0.108^{*}$ & $0.074^{*}$ & 0.146 & $0.091^{*}$ & $0.074 *$ & $0.135^{*}$ \\
\hline$\gamma_{\mathrm{ii}}$ & $0.392 *$ & $0.518^{*}$ & $0.290 *$ & $0.410^{*}$ & $0.371^{*}$ & $0.155^{*}$ & $0.389^{*}$ & $0.416^{*}$ & $0.174^{*}$ & $0.389 *$ & $0.400 *$ & $0.187^{*}$ \\
\hline$\gamma_{i j}$ & -0.007 & $-0.001^{*}$ & -0.092 & -0.015 & $0.065^{*}$ & -0.013 & 0.014 & 0.035 & $0.023^{*}$ & -0.001 & 0.014 & -0.004 \\
\hline$\gamma_{\mathrm{ji}}$ & -0.008 & $0.019^{*}$ & 0.180 & 0.017 & 0.011 & 0.023 & -0.001 & 0.013 & $-0.027^{*}$ & -0.006 & 0.017 & -0.019 \\
\hline$\gamma_{j j}$ & $0.283^{*}$ & $0.290^{*}$ & $0.252^{*}$ & $0.285^{*}$ & $0.277^{*}$ & $0.284 *$ & $0.260^{*}$ & $0.199^{*}$ & $0.329^{*}$ & $0.266^{*}$ & $0.214 *$ & $0.294^{*}$ \\
\hline$\delta_{\mathrm{ii}}$ & $0.868^{*}$ & $0.706^{*}$ & $0.698^{*}$ & $0.849^{*}$ & $0.928^{*}$ & $0.978^{*}$ & $0.876^{*}$ & $0.908^{*}$ & $0.973^{*}$ & $0.876^{*}$ & $0.914 *$ & $0.971^{*}$ \\
\hline$\delta_{i j}$ & 0.000 & -0.018 & 0.120 & $0.015^{*}$ & -0.016 & -0.014 & 0.003 & -0.012 & $0.002 *$ & 0.008 & -0.003 & 0.003 \\
\hline$\delta_{\mathrm{ji}}$ & 0.008 & $-0.007^{*}$ & 0.013 & 0.000 & $-0.005^{*}$ & -0.000 & 0.001 & -0.004 & 0.012 & 0.009 & -0.005 & 0.010 \\
\hline$\delta_{\mathrm{jj}}$ & $0.952 *$ & $0.946^{*}$ & $0.940^{*}$ & $0.948^{*}$ & $0.944 *$ & $0.960 *$ & $0.961^{*}$ & $0.977 *$ & $0.937 *$ & $0.958 *$ & $0.973 *$ & $0.949^{*}$ \\
\hline \multicolumn{13}{|c|}{ Panel B: Diagnostic tests } \\
\hline LogLik & -12735 & -8724 & -4022 & -12421 & -7458 & -3943 & -11243 & -6562 & -3630 & -10451 & -5912 & -3505 \\
\hline $\mathrm{LB}_{\mathrm{i}}$ & 30.789 & 50.52 & 13.02 & 32.396 & 152.8 & 16.4 & 29.272 & 147.5 & 18.84 & 29.461 & 145.8 & 17.45 \\
\hline $\mathrm{LB}_{\mathrm{j}}$ & 46.965 & 45.69 & 32.7 & 42.913 & 43.05 & 32.55 & 27.751 & 24.88 & 17.36 & 33.720 & 28.25 & 19.23 \\
\hline $\mathrm{LB}_{\mathrm{i}}^{2}$ & 38.584 & 28.42 & 50.86 & 35.404 & 48.19 & 25.89 & 40.329 & 50.76 & 27.95 & 40.124 & 49.08 & 25.38 \\
\hline $\mathrm{LB}^{2}{ }_{\mathrm{j}}$ & 28.462 & 24.02 & 20.96 & 31.503 & 33.75 & 24.98 & 40.828 & 34.11 & 38.74 & 37.776 & 40.61 & 33.06 \\
\hline
\end{tabular}

\subsection{Contagion Effects}


Further, we analyze if there have been pure contagion effects between African equity markets and the World market during the 2008 sub-prime crisis?

There is no one universal definition of contagion. Different authors use different definitions and different methodologies in quantifying contagion effects. Following Edwards (2000), we explain contagion as the instance, in which the degree of international transmission of shocks "far exceeds" market expectations. Existing literature confirms that liberalization leads to market integration, and in turn may result in increased contagion. Contagion from another standpoint is defined as the co-movement of the markets, especially in times of crisis. This definition is employed in this study to try to establish, if there were contagion effects during the 2008 US financial crisis in the African stock markets. The most severe part of the US financial crisis started in early September 2008, and it lasted for 6 months until early March 2009. It is estimated that the US stock market fell during that time by $43 \%$, the Emerging markets by $50 \%$, and frontier markets by $60 \%$ (Samarakoon 2011). To estimate the contagion effects, the used data is divided into two samples, namely to a sample that represents the "stable" pre-crisis period, and to a sample from during the crisis period. Following Forbes and Rigobon (2002), as a first step, we measure contagion by comparing the cross-market linkage at the time of the pre-crisis period and the same linkage during the crisis period, through correlation. For a survey on contagion effects globally, see, e.g., Dong \& Guo (2012).

Table 7. Tunisia

\begin{tabular}{|c|c|c|c|c|c|c|c|c|c|c|c|c|}
\hline \multicolumn{13}{|c|}{ Panel A: VAR(1)- GARCH(1. 1)-BEKK estimations } \\
\hline & \multicolumn{3}{|c|}{ TUNISIA - BRIC } & \multicolumn{3}{|c|}{ TUNISIA - EM } & \multicolumn{3}{|c|}{ TUNISIA - US } & \multicolumn{3}{|c|}{ TUNISIA - WORLD } \\
\hline & $\begin{array}{c}\text { Full- } \\
\text { Sample }\end{array}$ & $\begin{array}{l}\text { Pre- } \\
\text { Crisis }\end{array}$ & $\begin{array}{l}\text { Crisis- } \\
\text { Period }\end{array}$ & $\begin{array}{c}\text { Full- } \\
\text { Sample }\end{array}$ & $\begin{array}{c}\text { Pre- } \\
\text { Crisis }\end{array}$ & $\begin{array}{l}\text { Crisis- } \\
\text { Period }\end{array}$ & $\begin{array}{c}\text { Full- } \\
\text { Sample }\end{array}$ & $\begin{array}{l}\text { Pre- } \\
\text { Crisis }\end{array}$ & $\begin{array}{l}\text { Crisis- } \\
\text { Period }\end{array}$ & $\begin{array}{c}\text { Full- } \\
\text { Sample }\end{array}$ & $\begin{array}{l}\text { Pre- } \\
\text { Crisis }\end{array}$ & $\begin{array}{l}\text { Crisis- } \\
\text { Period }\end{array}$ \\
\hline Parameters & Coeff. & Coeff. & Coeff. & Coeff. & Coeff. & Coeff. & Coeff. & Coeff. & Coeff. & Coeff. & Coeff. & Coeff. \\
\hline $\boldsymbol{\beta}_{\mathrm{ii}}$ & -0.017 & 0.020 & $-0.07 *$ & -0.017 & 0.016 & $-0.070^{*}$ & -0.019 & 0.014 & $-0.080^{*}$ & -0.020 & 0.013 & $-0.075^{*}$ \\
\hline$\beta_{\mathrm{ij}}$ & 0.011 & $0.014 *$ & 0.013 & 0.009 & $0.015^{*}$ & 0.004 & 0.013 & 0.002 & $0.061 *$ & 0.011 & 0.013 & $0.036^{*}$ \\
\hline$\beta_{\mathrm{ji}}$ & 0.030 & 0.034 & -0.00 & 0.005 & 0.006 & 0.000 & $0.044^{*}$ & $0.046^{*}$ & 0.016 & 0.012 & $0.032 *$ & $-0.058^{*}$ \\
\hline $\boldsymbol{\beta}_{\mathrm{jj}}$ & 0.021 & 0.020 & 0.015 & 0.016 & $0.036^{*}$ & $-0.051^{*}$ & $-0.046^{*}$ & $-0.044^{*}$ & -0.025 & $0.140^{*}$ & $0.146^{*}$ & $0.141^{*}$ \\
\hline$\omega_{\mathrm{ii}}$ & $0.145^{*}$ & $0.111^{*}$ & $0.312 *$ & $0.142 *$ & $0.114^{*}$ & $0.341 *$ & $0.152^{*}$ & $0.128^{*}$ & $0.626^{*}$ & $0.151^{*}$ & $0.134 *$ & $0.705^{*}$ \\
\hline$\omega_{\mathrm{ij}}$ & $0.033^{*}$ & $0.248^{*}$ & $0.078^{*}$ & $0.067^{*}$ & $0.308^{*}$ & 0.083 & 0.010 & $0.058^{*}$ & $0.093 *$ & 0.009 & $0.095^{*}$ & $0.147^{*}$ \\
\hline$\omega_{\mathrm{jj}}$ & $0.214^{*}$ & $0.165^{*}$ & 0.000 & $0.215^{*}$ & 0.087 & -0.064 & $0.111^{*}$ & $-0.058^{*}$ & $0.134 *$ & $0.092^{*}$ & 0.041 & $-0.106^{*}$ \\
\hline$\gamma_{\mathrm{ii}}$ & $0.257^{*}$ & $0.181^{*}$ & $0.419^{*}$ & $0.255^{*}$ & $0.176^{*}$ & $0.422 *$ & $0.257^{*}$ & $0.198^{*}$ & $0.543^{*}$ & $0.264^{*}$ & $0.199^{*}$ & $0.595^{*}$ \\
\hline$\gamma_{i j}$ & -0.014 & $0.145^{*}$ & $-0.113^{*}$ & 0.021 & $0.133^{*}$ & -0.079 & 0.029 & $0.109^{*}$ & 0.014 & 0.001 & $0.067^{*}$ & -0.012 \\
\hline$\gamma_{j i}$ & 0.004 & 0.006 & $0.034^{*}$ & 0.002 & 0.005 & 0.038 & -0.006 & -0.000 & $-0.180^{*}$ & $-0.015^{*}$ & 0.000 & $-0.280^{*}$ \\
\hline$\gamma_{\mathrm{jj}}$ & $0.297^{*}$ & $0.322 *$ & $0.275^{*}$ & $0.291^{*}$ & $0.323^{*}$ & $0.276^{*}$ & $0.259^{*}$ & $0.232 *$ & $0.291 *$ & $0.257^{*}$ & $0.249^{*}$ & $0.268^{*}$ \\
\hline $\boldsymbol{\delta}_{\mathrm{ii}}$ & $0.951^{*}$ & $0.973^{*}$ & $0.844^{*}$ & $0.953^{*}$ & $0.973^{*}$ & $0.826^{*}$ & $0.950^{*}$ & $0.965^{*}$ & $0.495^{*}$ & $0.948^{*}$ & $0.965^{*}$ & $0.238^{*}$ \\
\hline$\delta_{\mathrm{ij}}$ & 0.006 & $-0.053^{*}$ & $0.040^{*}$ & -0.007 & $-0.059 *$ & 0.024 & -0.007 & $-0.026^{*}$ & -0.083 & 0.000 & $-0.025^{*}$ & -0.088 \\
\hline$\delta_{\mathrm{ji}}$ & -0.002 & $-0.006^{*}$ & $-0.001^{*}$ & -0.002 & $-0.008^{*}$ & 0.002 & 0.000 & -0.004 & $0.075^{*}$ & 0.004 & -0.007 & $0.161^{*}$ \\
\hline $\boldsymbol{\delta}_{\mathrm{jj}}$ & $0.947^{*}$ & $0.928^{*}$ & $0.958^{*}$ & $0.946^{*}$ & $0.920^{*}$ & $0.959^{*}$ & $0.961^{*}$ & $0.967 *$ & $0.956^{*}$ & $0.962 *$ & $0.959^{*}$ & $0.970 *$ \\
\hline \multicolumn{13}{|c|}{ Panel B: Diagnostic tests } \\
\hline LogLik & -11915 & -8167 & -3785 & -11607 & -7927 & -3717 & -10444 & -7048 & -3415 & -9647 & -6383 & -3284 \\
\hline $\mathrm{LB}_{\mathrm{i}}$ & 39.729 & 49.81 & 26.94 & 39.628 & 49.62 & 26.62 & 39.605 & 49.29 & 28.92 & 39.758 & 49.05 & 27.63 \\
\hline $\mathrm{LB}_{\mathrm{j}}$ & 45.836 & 43.21 & 32.79 & 43.411 & 39.81 & 32.16 & 26.180 & 24.22 & 19.2 & 32.043 & 27.79 & 21.65 \\
\hline $\mathrm{LB}^{2}{ }_{\mathrm{i}}$ & 34.354 & 21.27 & 40.54 & 36.114 & 23.19 & 39.83 & 35.027 & 18.7 & 44 & 33.595 & 18.22 & 51.5 \\
\hline $\mathrm{LB}^{2}{ }_{\mathrm{j}}$ & 23.988 & 17.92 & 24.05 & 29.811 & 22.48 & 25.05 & 44.346 & 23.12 & 42.78 & 44.390 & 25.84 & 35.16 \\
\hline
\end{tabular}

Table 1 panels B \& C show the correlations between the markets, it can be understood from the table that before 
the US financial crisis of 2008 the correlation between the markets under consideration is very low, and it becomes very high during the crisis period and thereafter. In our statistical analysis we use Pearson product-moment method to check the statistical significance for the correlation coefficients; all the correlation coefficients are statistically significant at the 5\% level of significance. By using the Wald test and the Chow test we checked the stability of correlation coefficients for both pre-crisis, and for the crisis period for comparison, both tests confirm the stability of correlation coefficients.

In addition to pairwise correlations, we again utilize VAR-GARCH-BEKK model to identify the pure contagion, both in returns and in volatility. Our results, presented in Tables 2-8, confirm that all the markets were prone to contagion from the US and the World markets (see, crisis period column in the tables). Our analysis shows that there were pure contagion effects during the US financial crisis of 2008. Kenya, South Africa, Egypt, and Mauritius were the most affected countries during the crisis period. This is not unexpected in light of the results presented earlier.

Table 8. Zambia

\begin{tabular}{|c|c|c|c|c|c|c|c|c|c|c|c|c|}
\hline \multicolumn{13}{|c|}{ Panel A: VAR(1)- GARCH(1. 1)-BEKK estimations } \\
\hline & \multicolumn{3}{|c|}{ ZAMBIA - BRIC } & \multicolumn{3}{|c|}{ ZAMBIA - EM } & \multicolumn{3}{|c|}{ ZAMBIA - US } & \multicolumn{3}{|c|}{ ZAMBIA - WORLD } \\
\hline & Full- & Pre- & Crisis- & Full- & Pre- & Crisis- & Full- & Pre- & Crisis- & Full- & Pre- & Crisis- \\
\hline & Sample & Crisis & Period & Sample & Crisis & Period & Sample & Crisis & Period & Sample & Crisis & Period \\
\hline Parameters & Coeff. & Coeff. & Coeff. & Coeff. & Coeff. & Coeff. & Coeff. & Coeff. & Coeff. & Coeff. & Coeff. & Coeff. \\
\hline $\boldsymbol{\beta}_{\mathrm{ii}}$ & 0.004 & $-0.042^{*}$ & $0.114^{*}$ & 0.004 & $-0.043^{*}$ & $0.108^{*}$ & 0.003 & $-0.040^{*}$ & $0.108^{*}$ & 0.008 & $-0.037^{*}$ & $0.110 *$ \\
\hline $\boldsymbol{\beta}_{\mathrm{ij}}$ & $0.039 *$ & 0.008 & $0.063 *$ & $0.046^{*}$ & 0.017 & $0.053^{*}$ & $0.030 *$ & -0.028 & $0.099 *$ & $0.050^{*}$ & -0.019 & $0.117 *$ \\
\hline $\boldsymbol{\beta}_{\mathrm{ji}}$ & 0.014 & $0.025^{*}$ & -0.002 & 0.010 & 0.024 & -0.000 & 0.006 & 0.013 & -0.029 & 0.004 & 0.008 & -0.016 \\
\hline $\boldsymbol{\beta}_{\mathrm{j} j}$ & 0.011 & 0.028 & -0.000 & 0.004 & $0.043^{*}$ & $-0.057^{*}$ & $-0.045^{*}$ & $-0.040 *$ & $-0.062^{*}$ & $0.137^{*}$ & $0.157 *$ & 0.094* \\
\hline$\omega_{\mathrm{ii}}$ & $0.221 *$ & $0.164 *$ & $0.318^{*}$ & $0.212^{*}$ & $0.180^{*}$ & $0.248^{*}$ & $0.254 *$ & $0.216^{*}$ & $0.350^{*}$ & $0.252^{*}$ & $0.193 *$ & $0.335^{*}$ \\
\hline$\omega_{\mathrm{ij}}$ & 0.059 & $-0.248 *$ & 0.055 & 0.046 & $-0.240 *$ & $0.087 *$ & -0.028 & $-0.046^{*}$ & -0.002 & $-0.022 *$ & $-0.048 *$ & -0.016 \\
\hline$\omega_{\mathrm{jj}}$ & $0.232^{*}$ & $0.245^{*}$ & $0.148^{*}$ & $0.232 *$ & $0.252^{*}$ & -0.000 & $0.106^{*}$ & $0.067 *$ & $0.148^{*}$ & $0.086^{*}$ & $0.071^{*}$ & $0.131^{*}$ \\
\hline$\gamma_{\mathrm{ii}}$ & $0.265^{*}$ & $0.201^{*}$ & $0.430 *$ & $0.267^{*}$ & $0.208 *$ & $0.331 *$ & $0.304 *$ & $0.239^{*}$ & $0.460^{*}$ & $0.301^{*}$ & $0.218^{*}$ & $0.461^{*}$ \\
\hline$\gamma_{\mathrm{ij}}$ & $-0.034 *$ & $-0.037 *$ & -0.007 & -0.020 & $-0.027 *$ & $-0.056^{*}$ & -0.011 & -0.010 & -0.026 & -0.005 & -0.006 & 0.000 \\
\hline$\gamma_{\mathrm{ji}}$ & $0.051^{*}$ & $-0.040^{*}$ & $-0.093^{*}$ & $0.045^{*}$ & $-0.026^{*}$ & $0.102 *$ & 0.007 & 0.002 & $-0.108^{*}$ & -0.003 & -0.023 & $-0.184 *$ \\
\hline$\gamma_{\mathrm{jj}}$ & $0.311^{*}$ & $0.350^{*}$ & $0.271 *$ & $0.300^{*}$ & $0.337^{*}$ & $0.281 *$ & $0.258^{*}$ & $0.213^{*}$ & $0.318^{*}$ & $0.255^{*}$ & $0.243 *$ & $0.279^{*}$ \\
\hline$\delta_{\mathrm{ii}}$ & $0.955^{*}$ & $0.974 *$ & $0.870^{*}$ & $0.956^{*}$ & $0.973^{*}$ & 0.918* & $0.944 *$ & $0.964^{*}$ & $0.855^{*}$ & $0.945^{*}$ & $0.970^{*}$ & $0.848^{*}$ \\
\hline$\delta_{\mathrm{ij}}$ & $0.011^{*}$ & $0.010^{*}$ & $-0.037^{*}$ & 0.006 & $0.008 *$ & $0.042 *$ & 0.005 & $0.004^{*}$ & 0.002 & 0.003 & 0.003 & -0.014 \\
\hline$\delta_{\mathrm{ji}}$ & $-0.022 *$ & $0.028 *$ & $0.039 *$ & $-0.018^{*}$ & $0.026^{*}$ & $-0.042^{*}$ & 0.000 & 0.002 & $0.045^{*}$ & 0.004 & $0.012 *$ & $0.073^{*}$ \\
\hline$\delta_{\mathrm{jj}}$ & $0.941^{*}$ & $0.914 *$ & $0.963^{*}$ & $0.943^{*}$ & $0.913^{*}$ & $0.955^{*}$ & $0.962 *$ & $0.974^{*}$ & $0.944 *$ & $0.963^{*}$ & $0.965^{*}$ & $0.957^{*}$ \\
\hline \multicolumn{13}{|c|}{ Panel B: Diagnostic tests } \\
\hline LogLik & -14495 & -10333 & -4169 & -14194 & -10100 & -4095 & -12981 & -9213 & -3765 & -12249 & -8563 & -3682 \\
\hline $\mathrm{LB}_{\mathrm{i}}$ & 29.495 & 40.56 & 27.24 & 30.332 & 40.6 & 30.21 & 31.366 & 39.42 & 28.38 & 31.085 & 40.27 & 27.98 \\
\hline $\mathrm{LB}_{\mathrm{j}}$ & 46.294 & 40.72 & 32.14 & 43.884 & 39.24 & 32.89 & 26.149 & 25.11 & 17.18 & 32.120 & 27.02 & 18.72 \\
\hline $\mathrm{LB}^{2}{ }_{\mathrm{i}}$ & 20.956 & 21.61 & 35.35 & 21.738 & 19.43 & 32.18 & 19.256 & 15.22 & 34.35 & 19.643 & 17.44 & 36.05 \\
\hline $\mathrm{LB}^{2}{ }_{\mathrm{j}}$ & 24.094 & 19.15 & 24.55 & 28.443 & 20.93 & 24.81 & 45.408 & 25.37 & 45.52 & 46.362 & 27.78 & 36.76 \\
\hline
\end{tabular}


Panel B in the Table 2-8 presents Ljung-Box Q-statistic for 15 lags, and shows that there is no dependence in the standardized and squared residuals. This underscores the fitness of the GARCH-BEKK model to be used with this data.

\section{Conclusion}

The existence of integration between the South African, Egyptian, The US, and The World markets has been extensively established in the literature, it is therefore not surprising that the results of this study confirmed these findings. Surprisingly, the level of integration between the Kenyan, the US, and the World markets is also found to be significant; this is a new finding. Kenya, like South Africa, exhibits a strong level of integration with all the indices used in this study, and especially with the USMI and the WMI.

Our empirical findings support the notion that these markets are still young and rather undeveloped, and that they can be used to create benefits in portfolio diversification. Diversification benefits with African stock markets are diminishing over the years, but the benefits do not disappear entirely. Furthermore, the increased correlations between the African and the developed markets are still small, when compared to the correlations between developed countries' markets (Harvey 1993). Divecha et al. (1992) found that these Emerging and Frontier Emerging markets, even though they are volatile, tend to be uncorrelated to other developed markets, signaling that investment into these markets may yield lower portfolio risks. We found that the correlation of African markets movement, with both regional and the World markets increased during the US subprime crisis, which suggests that the markets tend to move in tandem with the developed markets during bear markets. This leads to a conjecture that the benefits of diversifying investment across African stock markets could drop during crisis periods. This is not very different from what other studies have found previously.

\section{References}

Ahmed, A. D., \& Suardi, S. (2009). Macroeconomic volatility, trade and financial liberalization in Africa. World Development, 37(10), 1623-1636. http://dx.doi.org/10.1016/j.worlddev.2009.03.009

Ahmed, A. D. (2013). Effects of financial liberalization on financial market development and economic performance of the SSA region: An empirical assessment. Economic Modelling, 30, 261-273. http://dx.doi.org/10.1016/j.econmod.2012.09.019

Appiah-Kusi, J., \& Menyah, K. (2003). Return predictability in African stock markets. Review of Financial Economics, 12(3), 247-270. http://dx.doi.org/10.1016/S1058-3300(02)00073-3

Bekaert, G., \& Harvey, C. R. (1995). Time-varying world market integration. The Journal of Finance, 50(2), 403-444. http://dx.doi.org/10.1111/j.1540-6261.1995.tb04790.x

Bekaert, G., \& Urias, M. S. (1996). Diversification, Integration and Emerging Market Closed-End Funds. The Journal of Finance, 51(3), 835-869. http://dx.doi.org/10.1111/j.1540-6261.1996.tb02709.x

Bekaert, G., Harvey, C. R., \& Lumsdaine, R. L. (2002). Dating the integration of world equity markets. Journal of Financial Economics, 65(2), 203-247. http://dx.doi.org/10.1016/S0304-405X(02)00139-3

Bekaert, G., Harvey, C. R., \& Lundblad, C. T. (2003). Equity market liberalization in emerging markets. Journal of Financial Research, 26(3), 275-299. http://dx.doi.org/10.1111/1475-6803.00059

Bekaert, G., \& Campbell, R. H. (2003b). Market integration and contagion. No. w9510. National Bureau of Economic Research. http://dx.doi.org/10.3386/w9510

Bekaert, G., Harvey, C. R., \& Lundblad, C. (2005). Does financial liberalization spur growth? Journal of financial Economics, 77(1), 3-55. http://dx.doi.org/10.1016/j.jfineco.2004.05.007

Bekaert, G., Harvey, C. R., \& Lundblad, C. (2006). Growth volatility and financial liberalization. Journal of International Money and Finance, 25(3), 370-403. http://dx.doi.org/10.1016/j.jimonfin.2006.01.003

Beirne, J., Caporale, G. M., Schulze-Ghattas, M., \& Spagnolo, N. (2010). Global and regional spillovers in emerging stock markets: a multivariate GARCH-in-mean analysis. Emerging Markets Review, 11(3), 250-260. http://dx.doi.org/10.1016/j.ememar.2010.05.002

Billio, M., \& Caporin, M. (2010). Market linkages, variance spillovers, and correlation stability: Empirical evidence of financial contagion. Computational Statistics \& Data Analysis, 54(11), 2443-2458. http://dx.doi.org/10.1016/j.csda.2009.03.018

Bollerslev, T. (1986). Generalized autoregressive conditional heteroskedasticity. Journal of Econometrics, 31(3), 307-327. http://dx.doi.org/10.1016/0304-4076(86)90063-1 
Berndt, E., Hall, B., Hall, R., \& Hausman, J. (1974). Estimation and Inference in Nonlinear Structural Models. Annals of Economic and Social Measurement, 3, 653-665. Retrieved from http://www.nber.org/chapters/c10206

Divecha, A. B., Drach, J., \& Stefek, D. (1992). Emerging markets: a quantitative perspective. The Journal of Portfolio Management, 19(1), 41-50. http://dx.doi.org/10.3905/jpm.1992.409433

Dungey, M., Fry, R., \& Martin, V. L. (2004). Currency Market Contagion in the Asia-Pacific Region. Australian Economic Papers, 43(4), 379-395. http://dx.doi.org/10.1111/j.1467-8454.2004.00238.x

Engle, R. F. (1982). Autoregressive conditional heteroskedasticity with estimates of the variance of United Kingdom ination. Econometrica, 50, 987-1007. http://dx.doi.org/10.2307/1912773

Engle, R. F., \& Kroner, K. F. (1995). Multivariate simultaneous generalized ARCH. Econometric theory, 11(01), 122-150. http://dx.doi.org/10.1017/S0266466600009063

Edwards, S. (2000). Contagion. The World Economy, 23(7), 873-900. http://dx.doi.org/10.1111/1467-9701.00307

Forbes, K. J., \& Rigobon, R. (2002). No contagion, only interdependence: measuring stock market comovements. The Journal of Finance, 57(5), 2223-2261. http://dx.doi.org/10.1111/0022-1082.00494

Fowowe, B. (2011). The finance-growth nexus in Sub-Saharan Africa: Panel cointegration and causality tests. Journal of International Development, 23(2), 220-239. http://dx.doi.org/10.1002/jid.1660

Fowowe, B. (2013). Financial liberalization in sub-Saharan Africa: what do we know? Journal of Economic Surveys, 27(1), 1-37. http://dx.doi.org/10.1111/j.1467-6419.2011.00689.x

Gębka, B., \& Serwa, D. (2007). Intra-and inter-regional spillovers between emerging capital markets around the world. Research in International Business and Finance, 21(2), 203-221. http://dx.doi.org/10.1016/j.ribaf.2006.03.005

Harvey, C. R. (1993). Portfolio enhancement using emerging markets and conditioning information. In Stijn Claessens \& Shan Gooptu (Eds.), Portfolio investment in developing countries (pp. 110-144). Washington: The World Bank Discussion Series, 1993.

Karikari, J. A. (2010). Governance, Financial Liberalization, and Financial Development in Sub-Saharan Africa. (October) paper presented at the African Development Bank's African Economic Conference (pp. 27-29), Tunisia.

Kuttu, S. (2014). Return and volatility dynamics among four African equity markets: A multivariate $\begin{array}{llll}\text { VAR-EGARCH analysis. Global } & \text { Finance }\end{array}$ http://dx.doi.org/10.1016/j.gfj.2014.03.001

Misati, R. N., \& Nyamongo, E. M. (2011). Financial development and private investment in Sub-Saharan Africa. Journal of Economics and Business, 63(2), 139-151. http://dx.doi.org/10.1016/j.jeconbus.2010.10.001

Miller, M. H., Muthuswamy, J., \& Whaley, R. E. (1994). Mean reversion of Standard \& Poor's 500 index basis changes: arbitrage-induced or statistical illusion? Journal of Finance, 49, 479-513. http://dx.doi.org/10.1111/j.1540-6261.1994.tb05149.x

Miyakoshi, T. (2003). Spillovers of stock return volatility to Asian equity markets from Japan and the US. Journal of International Financial Markets, Institutions and Money, 13(4), 383-399. http://dx.doi.org/10.1016/S1042-4431(03)00015-5

Mlambo, C., \& Biekpe, N. (2005). Thin-trading on African stock markets: Implications on market efficiency testing. The Investment Analyst Journal, 61, 29-40.

Saleem, K. (2009). International linkage of the Russian market and the Russian financial crisis: A multivariate GARCH analysis. Research in International Business and Finance, 23(3), 243-256. http://dx.doi.org/10.1016/j.ribaf.2008.09.003

Saleem, K. (2013). Regional Integration: Evidence from African. African Journal of Business Management, 7(22), 2086-2096.

Singh, P., Kumar, B., \& Pandey, A. (2010). Price and volatility spillovers across North American, European and Asian stock markets. International Review of Financial Analysis, 19(1), 55-64. http://dx.doi.org/10.1016/j.irfa.2009.11.001

Samarakoon, L. P. (2011). Stock market interdependence, contagion, and the US financial crisis: The case of 
emerging and frontier markets. Journal of International Financial Markets, Institutions and Money, 21(5), 724-742. http://dx.doi.org/10.1016/j.intfin.2011.05.001

Tai, C. S. (2007). Market integration and contagion: Evidence from Asian emerging stock and foreign exchange markets. Emerging Markets Review, 8(4), 264-283. http://dx.doi.org/10.1016/j.ememar.2006.09.011

Wilcox, J. W. (1992). Taming frontier markets. The Journal of Portfolio Management, 19(1), 51-56. http://dx.doi.org/10.3905/jpm.1992.409431

Zhou, X., Zhang, W., \& Zhang, J. (2012). Volatility spillovers between the Chinese and world equity markets. Pacific-Basin Finance Journal, 20(2), 247-270. http://dx.doi.org/10.1016/j.pacfin.2011.08.002

\section{Notes}

Note 1. See, Fowowe $(2011,2013)$ to track the liberalization process in African equity markets.

Note 2. This model is based on the bivariate GARCH $(1,1)$-BEKK representation proposed by Engle and Kroner (1995).

\section{Copyrights}

Copyright for this article is retained by the author(s), with first publication rights granted to the journal.

This is an open-access article distributed under the terms and conditions of the Creative Commons Attribution license (http://creativecommons.org/licenses/by/3.0/). 